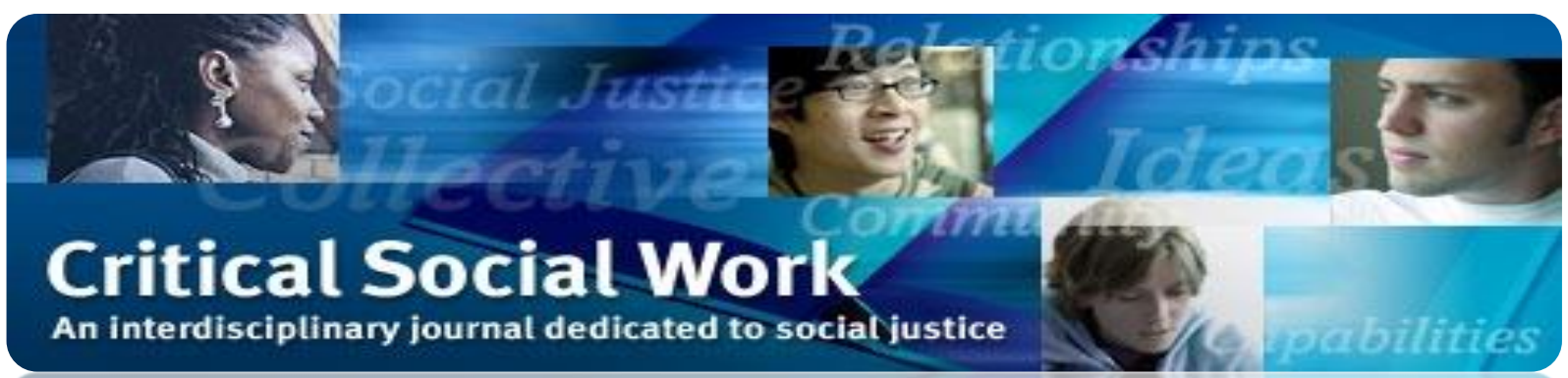

Critical Social Work

School of Social Work

University of Windsor

167 Ferry Street

Windsor, Ontario N9A 0C5

Email: cswedit@uwindsor.ca

Publication details, including instructions for authors and subscription information can be found at: http://uwindsor.ca/criticalsocialwork

Link to article:

http://www1.uwindsor.ca/criticalsocialwork/HeteronormativityNorwegianSWJournals

Critical Social Work, 2016 Vol. 17, No. 2 
Giertsen

\title{
Heteronormativity in Norwegian Social Work Journals
}

\section{Critical Social Work 17(2)}

\author{
Merethe Giertsen \\ University of Troms $\emptyset$, The Arctic University of Norway, Norway
}

\begin{abstract}
The purpose of this review was to examine whether heteronormativity is reproduced or problematized within Norwegian social work journals. It is based on a study that explored how sexuality is addressed in social work journal articles and extends past reviews by also analysing heterosexuality. The data comprised of 572 articles published in the major Norwegian social work journals between 2002 and 2014. A keyword search and a thematic analysis was used to first determine how many articles addressed sexuality and second to develop a closer analysis of how sexuality was addressed in the identified articles. Queer theory guided the analysis. Findings revealed that heteronormativity was problematized in five of the six (1\%) articles that addressed sexuality, indicating that heteronormativity is reproduced in Norwegian social work journals and that those in position in authority in the field of social work routinely deploy heterosexuality as a taken-for-granted resource. If power asymmetries are to be destabilized, strategies that counteract the power basis of the hegemonic norm are necessary, such as addressing the binary opposition of heterosexuality vs. non-heterosexuality, and naming heterosexuality.
\end{abstract}

Keywords: heteronormativity, sexuality, social work, queer theory, keyword search, thematic analysis 
Giertsen

The Norwegian Union of Social Educators and Social Workers (FO) and the International Federation of Social Workers (IFSW) share the goal of preventing discrimination based on sexual orientation (International Federation of Social Workers, 2012; Norwegian Union of Social Educators and Social Workers, 2014). Nevertheless, sexuality is marginalized, understudied, and under-theorized in social work education, research, and practice (Dunk-West \& HaffordLetchfield, 2011; Giertsen \& Innjord, 2009; Hicks, 2005; O'Brien, 1999; Wilton, 2000), as evidenced by the scarce studies found that address sexuality in social work journals (Clark \& Serovichs, 1997; Johnston \& Stewart, 2013; Phillips, Ingram, Grant Smith, \& Mindes, 2003; Scherrer \& Woodford, 2013; Van Voorhis \& Wagner, 2002). Queer theory, by which this article is informed, is a field of post-structuralist theory that emerged in the early 1990s, focusing on gender and sexuality categories. Important to queer theory, Foucault (1978) claimed, is that society produces different forms of knowledge, often in the form of various sciences to understand and talk about sexuality. Rather than liberating sexuality, these discursive formations work to construct and control sexuality. One important aspect of Foucault's research centers on the production of the homosexual: "We must not forget that the psychological, psychiatric, medical category of homosexuality was constituted from the moment it was characterized Westphal's famous article of 1870 on 'contrary sexual sensations' can stand as its date of birth ...." (Foucault, 1978, p. 43). By demonstrating that homosexuals did not exist before, Foucault shows that social identities result from the way in which knowledge is organized (Namaste, 1996).

Social work is usually concerned with lesbians, gay men, and bisexuals, and rarely with heterosexuality (Hicks, 2008b), reflecting the dominant position oppression models have in social work research, practice, education, policy, and advocacy work (McPhail, 2008). This view rests on a knowledge regime of binary categorizations, such as men/women, abled/disabled, wealthy/poor, and heterosexual/homosexual, in which the former groups are considered the privileged, and the latter groups, the marginalized or 'at risk' groups, receive special attention and concern (McPhail, 2008). Several scholars have pointed to how even the best intentions in work with sexual minorities reproduces heterosexuality as normative and preferred, and marginalizes non-heterosexuality (Hicks, 2008a; McPhail, 2008; Røthing, 2008), highlighting the need for sexuality studies within social work that include how heterosexuality is addressed.

Norway was early in enacting anti- and non-discrimination laws concerning sexuality. In 1981, Norway was the first country in the world to enact an anti-discrimination law, and in 1993, it was the second country in the world to enact a law on same-sex registered partnerships, which was replaced by a gender-neutral marriage law in 2008. Despite equality before the law, studies in Norway indicate that young Norwegians generally find it difficult and sometimes frightening to imagine themselves living a non-heterosexual life, therefore leading them to believe that suicide is still a reasonable reaction to having to face a future as a non-heterosexual (Hellesund, 2007; Røthing \& Svendsen, 2010). The results of a recent national survey in Norway on attitudes towards lesbian, gay, bisexual, and trans persons is consistent with these studies. A substantial proportion of those sampled, particularly men, had negative views when confronted with various statements: among men, 39\% agreed that sex between men is simply wrong, $22 \%$ agreed that sex between women is simply wrong, and $24 \%$ agreed that gays are repulsive (Anderssen \& Malterud, 2013). 
Giertsen

\section{Sexuality as Discourse}

The idea of sexuality as something that is produced through discourse (i.e., forms of talk or regulated statements, and practices that produce "the objects of which they speak;" Foucault, 1972/2002, p. 54) draws on the shared notion in post-structural philosophy and queer thinking that language shapes our perception of reality (Namaste, 1996).

In Western culture, sexuality exists as "a way of thinking that divides bodies, desires, and actions into a series of discrete 'types', such as 'the lesbian', 'the gay man', 'the bisexual', or 'the heterosexual'" (Hicks, 2005, p. 142). As constructed ideas, these 'types' or labels are part of a discourse that regulates what can and cannot be known or said. Appropriately, Hare-Mustin (1994) stated, "We do not only use the language, it uses us. Language is recursive: it provides the categories in which we think" (p. 22). It is difficult (and sometimes impossible) to think in other than gender-specific terms, such as men, women, heterosexual, and homosexual. We can try to use other terms to signify the direction of attraction (Søndergaard, 1996), but often we translate them back to common-sense terms. From this perspective, language does not represent reality; it constructs reality by producing representations of reality (Jørgensen \& Phillips, 1999).

A Foucaultian view of discourse highlights the ways in which our use of language reflects hidden ideologies in regimes of truth (Egeland \& Jegerstedt, 2008). With respect to sexuality, heteronormativity is the dominant discourse that permeates language, the way our society is organized, and suggests to us what has social value. Heteronormativity is defined in this article as "the institutions, structures of understanding, and practical orientations that make heterosexuality seem not only coherent - that is, organized as a sexuality - but also privileged" (Berlant \& Warner, 1998, p. 548).

Queer theory explores how the dominant discourse of heteronormativity produces and reproduces the hegemony of heterosexuality (Seidman, 1997). There are three central features in the discourse of heteronormativity. First, heteronormativity is the cultural bias in favour of opposite-sex relationships. Heteronormativity sustains the dominant norm of heterosexuality by rendering the diversity of human sexuality invisible (Hudak \& Giammattei, 2010). A similar process that upholds the privilege of heterosexuality is othering, in which heterosexuality "appears to be 'normal' and desirable in contrast to homosexuality as 'the other', not-normal, and unwanted by implication" (Røthing, 2008, p. 260). Second, as Hudak and Giammattei (2010) elaborate on, the silence around heterosexuality maintains it as the default position, which is a position of dominance and superiority. For example, the terms couple or family generally refer to heterosexual couples or heterosexual families. Other couples and families must be named gay or lesbian because otherwise they would be invisible. Within this heteronormative discourse, heterosexuality and heterosexual forms of relating are considered the norm. This maintains the illusion that only lesbian, gay and bisexual individuals have a sexuality and that it is unnecessary to examine heterosexuality. Third, central to a poststructuralist understanding of heteronormativity is how subjects are produced and reproduced in hierarchical binary oppositions, such as heterosexuals and homosexuals, men and women, normal and deviant, us and them (Butler, 1990). From this perspective, sexual minorities that are marginalized by society are not just victims of power, but they are also produced by power and are an intrinsic part of how societies organize themselves (Beasley, 2005). 
Giertsen

There is no agreement within queer scholarship whether sexuality can be studied separately from gender. Butler (1990) insists on an analytical connection between gender and sexuality, whereas Sedgwick (1990/2008, p. 31) argues that sexuality and gender should be analysed separately. Although, it is true that the concepts of homo- and heterosexuality could not exist without the concept of gender, many other dimensions of sexual choice have no such definitional connection with gender. In this study, I follow Sedgwick and make an analytical distinction between sexuality and gender. Although I see gender and sexuality as empirically related, the focus in this study is on sexuality. Therefore, the operationalization of sexuality (see the Method section) does not include gender/transgender categories.

\section{Current Study}

In this article, I seek to explore how sexuality, including heterosexuality, is addressed in Norwegian social work journal articles. Social work journals were chosen because material covered in professional journals communicates what is important in the field. Professional journals can also be understood as footprints by which the development of knowledge in a discipline or a profession can be traced (Bush, Epstein, \& Saintz, 1997, p. 46). Akin to Hicks and Watson (2003), I believe the journal articles themselves to be practices, not just theory which may or may not influence something called practice, and therefore worthy of study in their own right. The purpose of this review was to examine whether heteronormativity is reproduced or problematized within Norwegian social work journals. To the best of my knowledge, no studies have previously reviewed how sexuality is addressed in Norwegian social work journals. With this study, I sought to extend research into sexuality in social work journals to include a focus on heterosexuality. The aim of the study was to first determine how many articles addressed sexuality and second to develop a closer analysis of how sexuality was addressed.

\section{The Data}

\section{Method}

I conducted an analysis of articles published in the four (and only) peer-reviewed Norwegian social work journals between 2002 and 2014 that address Norwegian social workers: Fokus på Familien [Journal of Family Studies], Fontene Forskning [Fountain Research], Nordisk Sosialt Arbeid [Nordic Social Work] and Tidsskriftet Norges Barnevern [Journal of Norwegian Child Welfare]. The journal Nordic Social Work, which covers social work issues in the Nordic countries, was included because of its importance in the Norwegian social work context. This relates to similarities between the Nordic countries, both culturally and in relation to their welfare systems. Articles written by scholars dealing with questions in another Nordic country are therefore highly relevant in the Norwegian context as well. Peer-reviewed journals were included because they have impact both nationally and internationally on the professional social work community. Empirical articles and articles with an exclusively theoretical approach were examined $(N=572)$. Editorials, book reviews, discussions, and comments were excluded.

\section{Operationalizing Sexuality}

Analysing the production and reproduction of sexuality categories is a core point of queer theory. Consistent with this, I operationalize the concept of sexuality into categories of 
Giertsen

sexuality, such as bisexual, gay, heterosexual, lesbian, queer, and categories that designate a focus on sexuality, such as heteronormativity. In this article, I use the phrase sexual categories as shorthand for all of these categories.

\section{Analytical Strategy}

First, to determine how many articles addressed sexuality, a keyword search was conducted. The search included finding articles that addressed sexuality as a topic of the article itself, as part of the analysis, or simply (but importantly for the theory used in this analysis) to narrow the subject under study (e.g., heterosexual families). Articles in which sexuality was only sporadically mentioned, such as in a brief comment or in a footnote, were excluded. The search included Norwegian, English, Danish, and Swedish keywords because the four journals also publish articles in these languages. The keywords were homo, hetero, seksuell, seksualitet, sexualitet, sexuell, sexual, bifil, biseksuell, biseksualitet, bisexual, queer, skeiv, gay, lesbisk, and lesbian. Truncated versions of the search terms with a wildcard character to find all versions of the terms of interest were used, such as hetero* to find all words that start with hetero (heterosexual, heterosexuality, heteronormativity, etc.). Full text electronic versions of articles from 2002 were available. This made it possible to do full text keyword searches of the articles (rather than searching only titles). When reporting the results from the qualitative data analysis, I present quotations to show how sexual categories are used in journal articles, followed by an analysis of how the quotations epitomize the themes.

Second, a thematic analysis was used to analyze more closely how sexuality was addressed in the identified articles. Thematic analysis is "a method for identifying, analysing and reporting patterns (themes) within the data" (Braun \& Clarke, 2006, p. 6) and can be applied both inductively and deductively, at a semantic level and a latent level, by diverse theoretical approaches. A latent approach, which aims "to identify or examine the underlying ideas, assumptions, conceptualisations - and ideologies ..." (Braun \& Clarke, 2006, p. 13) was chosen. Two themes as expressions of the latent content were defined based on whether the focus on sexuality could be understood to problematize heteronormativity or if it could be understood to reproduce heteronormativity. A clear pattern was present, in that, each article was easily subsumed under one of the two theme (regarding the way in which sexuality was addressed). When reporting the results from the qualitative data analysis, I present quotations to show how sexual categories are used in the journal articles.

\section{Results}

\section{Keyword Search}

The distribution of the 572 examined articles by journal resulting from the keyword search for sexual categories are presented in Table 1. For each journal, the number of articles, number of sexuality-related articles, authors' names, year of publication, area of focus, and sexual categories used in the articles are listed. 
Giertsen

Table 1

Articles in Norwegian social work journals between 2002 and 2014 that address sexuality

\begin{tabular}{|c|c|c|c|c|}
\hline Journal & $\begin{array}{l}\text { Number } \\
\text { of } \\
\text { articles }\end{array}$ & $\begin{array}{l}\text { Number } \\
\text { of articles } \\
\text { addressing } \\
\text { sexuality }\end{array}$ & $\begin{array}{l}\text { Author(s), } \\
\text { publication year and } \\
\text { area of focus }\end{array}$ & $\begin{array}{l}\text { Sexual categories used } \\
\text { in the articles (in } \\
\text { English) }\end{array}$ \\
\hline \multirow[t]{4}{*}{$\begin{array}{l}\text { Fokus på familien } \\
\text { [Journal of Family } \\
\text { Studies] (2002-14) }\end{array}$} & \multirow[t]{4}{*}{242} & \multirow[t]{4}{*}{$4(1.6 \%)$} & $\begin{array}{l}\text { Borell (2002), } \\
\text { Household and } \\
\text { family within } \\
\text { family research. }\end{array}$ & $\begin{array}{l}\text { Homosexuals, } \\
\text { heterosexuals }\end{array}$ \\
\hline & & & $\begin{array}{l}\text { Finseth (2010), } \\
\text { Drama-based } \\
\text { pedagogical } \\
\text { working methods. }\end{array}$ & $\begin{array}{l}\text { Homosexuality, gay, } \\
\text { homophobe, sexual } \\
\text { legning }\end{array}$ \\
\hline & & & $\begin{array}{l}\text { Sheehan (2009), } \\
\text { The concept of } \\
\text { couple within the } \\
\text { family therapy } \\
\text { literature. }\end{array}$ & $\begin{array}{l}\text { Sexual, homosexuals, } \\
\text { gays, heterosexuals, } \\
\text { heterosexuality, } \\
\text { lesbians }\end{array}$ \\
\hline & & & $\begin{array}{l}\text { Øfsti (2008), The } \\
\text { romantic discourse } \\
\text { taken for granted in } \\
\text { couples therapy. }\end{array}$ & $\begin{array}{l}\text { Sexuality, } \\
\text { heterosexuality, gays, } \\
\text { lesbians, asexuality, } \\
\text { heteronormativity }\end{array}$ \\
\hline
\end{tabular}

Fontene Forskning $76 \quad 0(0 \%)$

[Fountain

Research] (2008-

14)

\begin{tabular}{|c|c|c|c|c|}
\hline $\begin{array}{l}\text { Nordisk Sosialt } \\
\text { Arbeid [Nordic } \\
\text { Social Work] } \\
(2002-08)\end{array}$ & 163 & $1(0.6 \%)$ & $\begin{array}{l}\text { Fahlgren \& Edvall } \\
(2006), \text { Gender } \\
\text { discourses in a } \\
\text { social work } \\
\text { textbook. }\end{array}$ & $\begin{array}{l}\text { Sexuality, } \\
\text { heterosexuality, } \\
\text { homosexuality, } \\
\text { heteronormativity }\end{array}$ \\
\hline $\begin{array}{l}\text { Tidsskriftet Norges } \\
\text { Barnevern [Journal } \\
\text { of Norwegian Child } \\
\text { Welfare] (2009-14) }\end{array}$ & 91 & $1(1.1 \%)$ & $\begin{array}{l}\text { Thørnblad (2009), } \\
\text { Public statements of } \\
\text { new guidelines on } \\
\text { choosing foster } \\
\text { homes. }\end{array}$ & $\begin{array}{l}\text { Gays, lesbians, } \\
\text { heterosexuals, sexual } \\
\text { legning, } \\
\text { heteronormativity }\end{array}$ \\
\hline$N=$ & 572 & $6(1 \%)$ & & \\
\hline
\end{tabular}


Giertsen

Sexuality was addressed in only six articles (1\%). The Journal of Family Studies published the largest number of sexuality-related articles (four articles), whereas Nordic Social Work, and the Journal of Norwegian Child Welfare published one each. No articles in Fountain Research addressed sexuality.

Five of the found articles (i.e., Borell, 2002; Fahlgren \& Edvall, 2006; Sheehan, 2009; Thørnblad, 2009; Øfsti, 2008) addressed sexuality in an extensive way, whereas one article (Finseth, 2010) addressed sexuality as part of the analysis. None of the articles narrowed the subject under study, e.g., heterosexual families.

The concepts of heterosexuality and homosexuality were used most often in the articles. Five of the six articles [all except for Finseth (2010] used homo* and hetero* categories (i.e., homosexuality/homosexuals/gays/lesbians and heterosexuality/heterosexuals), whereas none of the articles used bisexual*, queer or other sexual categories, such as androsexual (attraction to males and/or masculinity), gynesexual (attraction to women and/or femininity), or pansexual (attraction to members of all gender expressions). Finseth (2010) used several categories of homo* (homosexuality, gay, homophobe), but did not use any hetero* terms. Three articles used heteronormativity (Fahlgren \& Edvall, 2006; Thørnblad, 2009; Øfsti, 2008) and two (Finseth, 2010; Thørnblad, 2009) used the term sexual legning (a Norwegian term for the biological or genetic foundation for a sexual orientation [Hegna, 2007]). Øfsti (2008) used the greatest variety of sexual categories. In addition to homo* and hetero* categories, Øfsti used asexuality.

\section{Thematic Analysis}

Of the six articles that addressed sexuality, the five articles that did so extensively (Borell, 2002; Fahlgren \& Edvall, 2006; Sheehan, 2009; Thørnblad, 2009; Øfsti, 2008) questioned main notions of heteronormativity within the field of social work. Finseth (2010) was the only article to focus on homosexuality, and does not question heteronormativity.

Two articles problematized heteronormative assumptions relating to the concepts of household and family. Based on recent family research, Borell (2002) refers to homosexuality as a way to introduce the idea that the family concept is more complex than it is usually conceived. He used homosexual family relations as an example of families of choice, while maintaining that families of choice are not unique to homosexuals: "The ... active construction of family ties, however, is not unique to homosexuals" (Borell 2002, p. 265). As previously noted, the keyword search for sexual categories showed that Thørnblad (2009) used the concept of sexual legning. A closer examination of the article revealed that Thørnblad only used the concept of sexual legning when citing public statements. The way sexual legning, a concept reflecting an essentialistic discourse, was used in this article is consistent with the author's critical perspective. Thørnblads (2009) is a qualitative analysis of public statements regarding the proposal of new guidelines for choosing foster homes. The government proposed that foster homes should primarily consist of two foster parents of different genders' and that gay, lesbian, or single foster parents can be chosen if certain particular considerations were present (Thørnblad, 2009, p. 224). In her analysis, Thørnblad (2009) writes that the main discourse of the traditional family is still associated with choosing a foster family: "The heteronormative nuclear family continues, 
Giertsen

however, as a norm for the family constellations... a differentiation in family practises does not necessarily weaken the nuclear family as an ideal" (p. 230).

Sheehan (2009) and Øfsti (2008) focused on the concept of couples in the family therapy literature. With respect to intimate relations between adults, they both problematized the couple as the dominant idea in family therapy and social work. Sheehan (2009) argued for a wider frame than the couple, whether it be a heterosexual or a homosexual couple, "what implications would it have, if the marriage law were extended to include not only homosexual and heterosexual pairs, but to also include intimate units of three, four or five people?" (p. 111). Øfsti (2008) discussed the romantic discourse that is taken for granted in couples therapy. She pointed out how discourses in couples therapy lack concepts that reflect the complexity of living arrangements: "Practices such as 'fucking friends', asexual living arrangements in which the persons involved do not understand each other as just friends, committed sexual relations with several other persons? What should we call these relations?” Øfsti (2008, p. 371) asked. Øfsti (2008, p. 364) also examined how heteronormativity pervades and affects the fight for gay rights: "The fight to be included in the marriage law and the rights to in vitro fertilization and adoption are examples of how the heteronormative nuclear pattern is carried out, independent of the twogender model." The keyword search showed that Øfsti's article has the greatest variety of sexual categories. The concept of heteronormativity was also used more extensively, pointing to how gay politics can be understood as reproducing heteronormativity.

Fahlgren and Edvall (2006) is a discursive analytical reading of a textbook used to train social workers and is a guide to practical social work with addicts. The aim of the article was to show how normative meanings of gender continue to be produced and reproduced by gender discourses. They argued that women are being embodied as 'the other', as different, as body, and gender, and are being sexualized (Fahlgren \& Edvall, 2006, p. 70). They saw gender discourses and sexuality discourses as reinforcing each other: "The conceptualization of two genders is understandable (and 'natural') in accordance with heterosexuality as the norm, and concomitantly it makes heterosexuality the norm (and 'natural') because of the understanding of gender as two different and opposite bodies made for each other" (Fahlgren \& Edvall, 2006, p. 69).

In these five articles, central features in a heteronormative discourse were questioned. The cultural bias of favoring opposite-sex relationships was problematized and in doing so, they were naming the taken for granted and hegemonic cultural norm of heterosexuality. In this way, they problematized the hierarchical binary opposition of heterosexuality and non-heterosexuality. As such, these articles produced sexual landscapes more complex than allowed for in a heteronormative discourse.

Finally, Finseth (2010) presented various drama-based pedagogical methods of working with youths with social anxiety. Sexual legning was one of several subjects explored with the drama-based pedagogical working method (Finseth, 2010, p. 324). Finseth (2010) noted: "Subjects like friendship, falling in love, partying, alcohol, questions related to sexual legning, and identity ... We used creative working methods to deal with subjects the youth were interested in" (p. 324). One of the examples of a drama-based pedagogical working method involved a gay boy. The gay boy was presented in the text as having difficulty telling others he is 
Giertsen

homosexual: "[...] a sixteen-year-old gay boy who wished (but had not dared) to tell others he was gay" (Finseth 2010, p. 326). The gay vignette in Finseth's article also included $a$ homophobe: "The 'homophobe' was encouraged to sit in 'the hot seat'. This technique allows one to interview persons one would like to know better, such as a person who, as part of the method, has done something critical” (Finseth, 2010, p. 326).

The keyword search showed that only homo* words were used in the Finseth (2010) article; there were no hetero* words. The previously mentioned point by Hudak and Giammattei (2010) was thus illustrated in this article; the use of only homo* words maintained the illusion that only non-heterosexual individuals have a sexuality and that it is not necessary to examine heterosexuality. From a queer theoretical point of view, the Finseth (2010) article can be said to reproduce heteronormativity, as it framed homosexuality as problematic, individualized homonegativity into bad attitudes some people have, and did not discuss how heterosexuality is privileged.

\section{Discussion}

The purpose of this study was to explore how sexuality was addressed in Norwegian social work journal articles. Of the 572 reviewed articles, sexuality was addressed in only six (1\%) articles. Heteronormativity was problematized in five (0.9\%) articles (Borell, 2002; Fahlgren \& Edvall, 2006; Sheehan, 2009; Thørnblad, 2009; Øfsti, 2008). In the sixth article, Finseth (2010), homosexuality was framed as problematic and heteronormativity was not problematized. Such a minimal focus on sexuality within published literature suggests that heterosexuality is taken for granted, reflecting the high value put on heterosexuality, as the 'normal' and preferred sexual orientation.

My finding that sexuality was only addressed in one percent $(n=6)$ of articles, is similar to previous research of sexuality in social work journals. For example, Clark and Serovichs' (1997) study found the least, with only $0.006 \%(N=77)$ of the reviewed articles having included sexuality and Van Voorhis and Wagner (2002) found the highest, at 3.92\% (N=77) (and between these: Johnston \& Stewart (2013) with 0.03\% ( $N=50)$; Phillips et al. (2003) had 2.1\% $(N=119)$; Scherrer \& Woodford (2013) found 2.6\% (N=56)). However, as noted previously, these studies focused solely on lesbian, gay, bisexual, transsexual, queer (LGB/LGBTQ) issues, whereas the focus on sexuality in this study was wider, including not only minority categories, but sexuality categories, in general. The inclusion criteria in these studies were also narrower, as they only included articles with a significant focus on LGB/LGBTQ issues. In comparison, the inclusion criteria in the present study was broader, excluding only articles in which sexuality was sporadically mentioned (cf. the 'Method' section). For example, I included the Finseth (2010) article because sexual categories were used more than sporadically. However, relative to previous research, the Finseth article (2010) did not significantly focus on LGB issues because the gay vignette was only five paragraphs long and only one of several examples used to illustrate a social work method. Because of the wider focus on sexuality and broader inclusion criteria, compared with previous research, I would have expected that the number of articles addressing sexuality would be higher in this sample. Therefore, having none of the articles significantly address LGB issues, it is clear that LGB issues are examined to an even lesser extent in Norwegian social work journals than they are in international social work journals. 
Giertsen

A limited focus on sexuality is considered by Sedgwick (1990/2008, p. 8) to be "ignorance of a knowledge ... these ignorances, far from being pieces of the originary dark, are produced by and correspond to particular knowledges and circulate as part of particular regimes of truth". This type of knowledge regime not only renders sexual diversity invisible, but also upholds the hierarchical binary opposition of heterosexuality vs. non-heterosexuality. As Jeyasingham (2008, p. 147) stated it, "This system of knowledge/ignorance operates to keep certain ways of knowing sexuality out of circulation - not just discourses of queer desire and pleasure but also ways of questioning the significance that is attributed to the difference between 'heterosexual' and its others".

The strong emphasis on equality in the Norwegian welfare model, and a core cultural value in Norway, may help to explain why sexuality is hardly addressed in social work journals in Norway. Roseneil, Crowhurst, Hellesund, Santos, and Stoilova (2013) suggested that the welfare regime plays a role in the construction of sexuality. The legal equality in Norway concerning sexual orientation could, as suggested by Roseneil et al. (2013, p. 184), be understood as an expression of "having instituted equality as a firm principle of governance". Research (e.g., Andenæs, 2004; Kriz \& Skivenes, 2010; Østby, 2008) shows that social workers and social work educators in Norway typically identify problems and solutions at the individual level, lacking a focus on diversity, structural factors, and oppression. This same logic of a power/inequality blindness may also apply to social work scholars in Norway, at least concerning sexuality, and therefore contribute to understanding why sexuality is scarcely addressed in social work journals in Norway.

That only five articles problematized heteronormativity indicates that no other article in the sample narrowed their subject to include heterosexual youth or heterosexual families. O'Brien (1999) found a similar pattern in her examination of articles on lesbian, gay, and bisexual youth; no other social work publications cited them. She "suggests that there are processes through which they are constituted as a subordinate form of knowledge" (O'Brien, 1999, p. 146). Following the argument of Røthing and Svendsen (2010), such processes concern heterosexuality being valued to such a degree that no one, apart from those working specifically with heteronormativity issues, sees a need to problematize sexuality.

The manifest intent of Finseth (2010) was to show the applicability of various dramabased pedagogical working methods, one of which is sexual legning. When the gay boy was the one who had the problem - and when heteronormativity was left unchallenged - the centrality and invisibility of heterosexuality is maintained, which is a core aspect of the tradition of antidiscriminatory practice (Hicks, 2008a). Within this discourse, the rationale for social workers addressing sexuality is the belief that social work involves work "with those who are the disadvantaged in society" (Fish, 2012, p. 15). This approach is based on ideas derived from what Epstein (1987) termed the ethnic identity model of sexuality. This model promotes the idea of lesbians and gay men as a minority culture or a community-based interest group and it forms the basis of liberal, rights-based rhetoric (Hicks, 2008a). Although the ethnic identity model can claim political victories with respect to human rights, in light of liberation as a goal of social work, it fails to examine why sexual minorities came to be understood as minorities and how the hegemony of heterosexuality is (re)produced. 
Giertsen

A reverse discourse that produces positive images of homosexuals, as is often advocated by scholars working within an anti-discriminatory school of thought (e.g., see Fish, 2012; Gates \& Brian, 2012) will not solve the problem of homosexuality being framed as problematic. Within a binary understanding of sexuality, heterosexuality is still associated with the normal and desirable relative to homosexuality. From a post-structural and queer theoretical perspective, one would argue that heterosexuality needs homosexuality for its own definition (Namaste, 1996). Homophobia is thus built into a binary understanding of sexuality, as the hegemonic norm of heterosexuality is what homosexuality is not.

\section{A Final Reflection on Studying Identity-based Categories}

The way sexuality was operationalized in this study, including an identity-based set of categories, such as bisexual, gay, heterosexual, and lesbian, illustrates the kinds of paradoxes described by Hare-Mustin (1994), in which discursive practices uphold power relations. From a queer theoretical perspective, sexual identity-based categories are products of a knowledge regime aimed at controlling sexuality. However, queer theory recognizes the impossibility of moving outside current conceptions of sexuality. What we can do, queer theory suggests, is to think about how current conceptions create boundaries (Namaste, 1996).

Addressing critically the focus on homosexuality in the Finseth (2010) article, is not meant to disregard studies of lesbian and gay identities and communities. A sexual-minority focus has served to acknowledge sexual differences and has enabled political progress, as in removing discriminatory regulations (Francis 2012; Sedgwick, 1990/2008). Further, because of the absence of studies on homosexuals, as this study also illustrates, scholarship on homosexuality and homosexual identity is needed. However, as Namaste (1996, p. 202) points out: "... ironically, the attention accorded to homosexuality serves to strengthen the heterosexual/homosexual opposition even further". Therefore, I argue in this article that it is important for social work to pay attention to how power asymmetries are reproduced through the hegemonic and binary way of understanding sexuality.

\section{Practical Implications}

If power asymmetries are to be destabilized, strategies that counteract the power basis of the hegemonic norm are necessary. As earlier commented upon, the gay vignette in Finseth (2010) can be said to reproduce heteronormativity by framing homosexuality as problematic and by not problematizing heteronormativity. Instead of understanding the gay boy as having the problem, an alternative approach to this schoolroom situation, as well as in other social work arenas, is to problematize the binary opposition and hierarchical structure of heterosexuality vs. non-heterosexuality: Anderssen (2005) suggested that this could be done by reflecting on how sexual categories discipline all of us. Morton, Jeyasingham, and Hicks (2013) recommended reflecting on how sexuality in social interaction is done, with a particularly focus on what is taken for granted. Walls et al. (2009) proposes reflecting on heterosexual privileges. Fantus (2013) recommends using peoples' own personal narratives, rather than making assumptions based on prescribed categories. McPhail (2009, p. 17) suggests teaching critical questioning by asking questions such as "Whom do these categories serve? Who do these categories include,

and whom do they exclude? Who has the power to define the categories? How are the categories 
Giertsen

policed? How do these categories change over time and over cultures?" Finally, MacKinnon (2011) and McPhail (2009) argues for including queer theories in the social work curriculum.

When heteronormativity was problematized in only $0.9 \%$ of the reviewed articles reflects the taken for granted position regarding heterosexuality. I therefore suggest that social work, in policy documents, research, client-orientated work, and teaching should practise what Hudak and Giammattei (2009, p. 11) describes as "the simple but very powerful act of naming heterosexuality". This could seem counterproductive to queer-theoretical thinking, which has as a main goal to problematize sexual categories. However, using the concept of heterosexuality has two advantages. First, and most obviously, to not take heterosexuality for granted, and second, simultaneously producing an understanding of sexuality as a diverse phenomenon. As argued in this article, using categories should be done with caution. The suggestion to use peoples' own narratives (Fantus, 2013), instead of being understood accordingly to prescribed sexual categories, is therefore an important contribution in light of the binary way of understanding sexuality. However, if the hegemonic norm is silenced, this maintains heterosexuality as the default position, and non-heterosexuality as a deviation from that default.

\section{A Concluding Remark}

The main objective of this article was to examine whether heteronormativity is reproduced or problematized within Norwegian social work journals. The analysis showed that heteronormativity was problematized in five of the six (1\%) articles that addressed sexuality. Social workers who would like to prevent discrimination and marginalization based on sexuality face considerable problems because their professional literature takes the norm of heterosexuality for granted. If hegemonic knowledge regimes within social work are not critically explored, social work is in danger of reproducing hegemonic understandings of sexuality and, in so doing, marginalizing those who do not fit into heterosexuality's hegemonic mold. 
Giertsen

\section{References}

Andenæs, A. (2004). Hvorfor ser vi ikke fattigdommen? En undersøkelse om barn som blir plassert utenfor hjemmet [Why do we not pay more attention to the problems of poverty within the field of child protection?]. Nordisk sosialt arbeid [Nordic Social Work], 24(1), 19-33.

Anderssen, N. (2005). Seksuelle kategoriers regulering [Regulative forces of sexual categories]. Impuls: Tidsskrift for Psykologi [Impulse: Journal of Psychology], 59(1), 23-30.

Anderssen, N., \& Malterud, K. (Eds.) (2013). Seksuell orientering og levekår [Sexual orientation and living conditions]. Retrieved from https://bora.uib.no/bitstream/handle/1956/7550/Seksuell_orientering_og_levek\%C3\%A5r .pdf? sequence $=1$

Beasley, C. (2005). Gender \& sexuality. Critical theories - critical thinkers. London, ENG: Sage.

Berlant, L., \& Warner, M. (1998). Sex in public. Critical Inquiry, 24(2), 547-566.

Borell, K. (2002). Hushåll och familj [Household and family]. Fokus på Familien [Journal of Family Studies], 30(4), 265-279.

Braun, V., \& Clarke, V. (2006). Using thematic analysis in psychology. Qualitative Research in Psychology, 3(2), 77-101. doi:10.1191/1478088706qp063oa

Bush, I. R., Epstein, I., \& Sainz, A. (1997). The use of social science sources in social work practice journals: An application of citation analysis. Social Work Research, 21(1), 4556. doi:10.1093/swr/21.1.45

Butler, J. (1990). Gender trouble. Feminism and the subversion of identity. New York, NY: Routledge.

Clark, W., \& Serovich, J. (1997). Twenty years and still in the dark? Content analysis of articles pertaining to gay, lesbian and bisexual issues in marriage and family therapy journals. Journal of Marital \& Family Therapy, 23(3), 239-253. doi:10.1111/j.17520606.1997.tb01034.x

Dunk-West, P., \& Hafford-Letchfield, T. (Eds.) (2011). Sexual identities and sexuality in social work. Farnham, ENG: Ashgate.

Egeland, C., \& Jegerstedt, K. (2008). Diskursiv tilnærming [Discursive approaches]. In E. Mortensen, C. Egeland, R. Gressgård, C. Holst, K. Jegerstedt, S. Rosland, \& K. Sampson (Eds.), Kjфnnsteorier [Gender Theories] (pp. 70-73). Bergen, NO: Gyldendal Akademisk.

Epstein, S. (1987). Gay politics, ethnic identity: The limits of social constructionism. Socialist Review, 17(3-4), 9-54.

Fahlgren, S., \& Edvall, H. (2006). Kulturella könsdiskursers makt - ett exempel från en utbildningstext [The power of gender discourses - an example from a textbook]. Nordisk Sosialt Arbeid [Nordic Social Work], 26(1), 62-73.

Fantus, S. (2013). The dichotomy of sexuality: A narrative-epistemological framework for social work practice and research. Critical Social Work, 14(2), 99-113.

Finseth, T. K. (2010). Da kreativiteten bød problemene opp til dans [Creativity and problems likely dancing partners?]. Fokus på Familien [Journal of Family Studies], 38(4), 319335.

Fish, J. (2012). Social work and lesbian, gay, bisexual and trans people: Making a difference. Chicago, IL: Policy Press. 
Giertsen

Norwegian Union of Social Educators and Social Workers (FO). (2014). Forbundets formål [Objective of the federation]. Retrieved from https://www.fo.no/fosformaal/category1072.html

Foucault, M. (1972/2002). Archaeology of knowledge. London, ENG: Routledge.

Foucault, M. (1978). The history of sexuality. New York, NY: Penguin.

Francis, M. (2012). On the myth of sexual orientation: Field notes from the personal, pedagogical, and historical discourses of identity. In M. Fitzgerald \& S. Rayter (Eds.), Queerly Canadian: An Introductory Reader in Sexuality Studies (pp. 1-22). Toronto, ON: Canadian Scholars' Press.

Giertsen, M., \& Innjord, A. K. (2009). Seksualitet. En distinksjon å regne med-også på sosialarbeiderutdanninger [Sexuality. A distinction to count in - in social work education as well]. HiF-Rapport: 6, Finnmark University College.

Hare-Mustin, R. (1994). Discourses in the mirrored room: A postmodern analysis of therapy. Family Process, 33(1), 19-36. doi:10.1111/j.1545-5300.1994.00019.x

Hegna, K. (2007). Coming out, coming into what? Identification and risks in the 'coming out' story of a Norwegian late adolescent gay man. Sexualities, 10(5), 582-602. doi: $10.1177 / 1363460707083170$

Hellesund, T. (2007). Deadly identities? Homosexuality, adolescence and parasuicide. Ethnologia Scandinavica, 37, 35-46.

Hellesund, T. (2008). Identitet på liv og d $\phi$ d. Marginalitet, homoseksualitet og selvmord [Identity for life and death. Marginality, homosexuality and suicide]. Oslo, NO: Spartacus.

Hicks, S. (2005). Sexuality: Social work theories and practice. In R. Adams, L. Dominelli, \& M. Payne (Eds.), Social work futures. Crossing boundaries, transforming practice (pp. 141153). Basingstoke, ENG: Palgrave Macmillan.

Hicks, S. (2008a). Thinking through sexuality. Journal of Social Work, 8(1), 65-82. doi:10.1177/1468017307084740

Hicks, S. (2008b). What does social work desire? Social Work Education, 27(2), 131-137. doi:10.1080/02615470701709451

Hicks, S., \& Watson, K. (2003). Desire lines: 'Queering' health and social welfare. Sociological Research Online, (8)1. Retrieved from http://www.socresonline.org.uk/8/1/hicks.html

Hudak, J., \& Giammattei, S. (2010). Doing family: Decentering heteronormativity in 'marriage' and 'family' therapy. In J. Ariel, P. Hernandez-Wolfe \& S. Stearns (Eds.), AFTA Monograph Series: Expanding our Social Justice Practices: Advances in Theory and Training (pp. 49-58). Washington, DC: American Family Therapy Academy.

International Federation of Social Workers (IFSW). (2012). Statement of ethical principles. Retrieved from http://ifsw.org/policies/statement-of-ethical-principles/

Jeyasingham, D. (2008). Knowledge/ignorance and the construction of sexuality in social work education. Social Work Education, 27(2), 138-151. doi:10.1080/02615470701709469

Johnston, L. B., \& Stewart, C. (2013). Still among the missing? A content analysis of LGBT articles in social work journals, 1998-2009. Journal of Gay \& Lesbian Social Services, 25(2), 232-243. doi:10.1080/10538720.2013.782741

Jørgensen, M. W., \& Phillips, L. (1999). Diskursanalyse som teori og metode [Discourse analysis as theory and method]. Fredriksberg, DK: Roskilde Universitetsforlag. 
Giertsen

Kriz, K. \& Skivenes, M. (2010). 'Knowing our society' and 'Fighting against prejudices': How child welfare workers in Norway and England perceive the challenges of minority parents. British Journal of Social Work, 40(8), 2634-2651. doi:10.1093/bjsw/bcq026

MacKinnon, K. V. R. (2011). Thinking about queer theory in social work education: A pedagogical (in)query. Canadian Social Work Review, 28(1), 139-144.

McPhail, B. A. (2008). Questioning gender and sexuality binaries. Journal of Gay \& Lesbian Social Services, 17(1), 3-21. doi:10.1300/J041v17n01_02

Morton, J., Jeyasingham, D., \& Hicks, S. (2013). The social work of sexuality: Rethinking approaches to social work education. Health and Social Care Education, 2(2), 16-19. doi:10.11120/hsce. 2013.00027

Namaste, K. (1996). The politics of inside/out: Queer theory, poststructuralism, and a sociological approach to sexuality. In S. Seidman (Ed.), Queer theory/sociology (pp. 194-212). Cambridge, MA: Blackwell Publ.

O’Brien, C. A. (1999). Contested territory: Sexuality and social work. In A. Chambon, A. Irving, \& L. Epstein (Eds.), Reading Foucault for Social Work (pp. 131-156). New York, NY: Columbia University Press.

Phillips, J., Ingram, K., Grant Smith, N., \& Mindes, E. (2003). Methodological and content review of lesbian-, gay-, and bisexual-related articles in counselling journals: 1990-1999. The Counselling Psychologist, 31(1), 25-62. doi:10.1177/0011000002239398

Roseneil, S, Crowhurst, I., Hellesund, T., Santos, A. C., \& Stoilova, M. (2013). Changing landscapes of heteronormativity: The regulation and normalization of same-sex sexualities in Europa. Social Politics, 20(2), 165-199. doi:10.1093/sp/jxt006

Røthing, А. (2008). Homotolerance and heteronormativity in Norwegian classrooms. Gender and Education, 20(3), 253-266. doi:10.1080/09540250802000405

Røthing, A. \& Svendsen, S. H. B. (2010). Homotolerance and heterosexuality as Norwegian values. Journal of LGBT Youth, 7(2), 147-166. doi:10.1080/19361651003799932

Scherrer, K., \& Woodford, M. (2013). Incorporating content on gay, lesbian, transgender, and queer issues in leading social work journals. Social Work Research, 37(4), 423-431. doi:10.1093/swr/svt031

Sheehan, J. (2009). Å nedtone betydningen av paret som idé når det gjelder intime relasjoner mellom voksne: Implikasjoner for familieterapiens teori og praksis. [To downplay the significance of the couple as an idea when it concerns intimate relationships between adults: Implications for the theory and practise in family therapy]. Fokus på Familien [Journal of Family Studies], 37(2), 99-113.

Sedgwick, E. K. (1990/2008). Epistemology of the closet. Berkeley, CA: University of California Press.

Seidman, S. (1997). Difference troubles: Queering social theory and sexual politics. Cambridge, UK: Cambridge University Press.

Søndergaard, D. M. (1996). Tegnet på kroppen: Køn, koder og konstruktioner blandt unge voksne i akademia [Sign on the body: Gender, codes and constructions among young adults in academia]. Copenhagen, DK: Museum Tusculanums Forlag.

Thørnblad, R. (2009). Slektsfosterhjem i offentlig barnevern [Kinship foster homes within public child care]. Norges Barnevern [Journal of Norwegian Child Welfare], 86(4), 220-235.

Van Voorhis, R., \& Wagner, M. (2002). Among the missing: Content on lesbian and gay people in social work journals. Social Work, 47(4), 345-354. doi:10.1093/sw/47.4.345 
Giertsen

Walls, N. E., Griffin, R., Arnold-Renicker, H., Burson, M., Johnston, C., Moorman, N ... Schutte, E. C. (2009). Mapping graduate social work student learning journeys about heterosexual privilege, Journal of Social Work Education, 45(2), 289-307. doi:10.5175/JSWE.2009.200800004

Wilton, T. (2000). Sexualities in health and social care: A textbook. Buckingham, ENG: Open University Press.

Øfsti, A. K. S. (2008). Om å ta den romantiske diskursen for gitt. Et essay om diskursiv parterapi [About taking the romantic discourse for granted. An essay about discursive couple therapy]. Fokus på Familien [Journal of Family Studies], 36(4), 362-374.

Østby, L. (2008). Rasisme eller kultur? Perspektiver i utdanning av sosialarbeidere i Norge og England [Racism or culture? Perspectives in the education of social workers in Norway and England]. Fontene Forskning [Fountain Research], 1, 49-61. 